\title{
Efficient Way to Improve Subgrade Property of Pavement by Chemical Stabilization
}

\author{
Rajshekhar G Rathod \\ Assistant Professor Maharashtra Institute of technology College of Engineering, Kothrud, Pune, India
}

\begin{abstract}
There are numerous soil stabilization techniques for improving the strength of the in-situ soil especially in road construction, and one of the techniques is using chemical additive. Chemical improvement is a time saving method that enables subgrade or sub-base layer and otherwise unsatisfactory materials in-situ to obtain higher density and strength, obviating the need for costly excavation and replacement with borrow material. This paper presents some results of the preliminary stages of research program carried out to explicate the mechanism and behavior between the liquid chemical and the engineering properties of three natural residual soils at laboratory scale. Liquid-formed chemical was selected in this research due to scarcity of such findings instead of the prevalent solid chemical additive such as lime, cement or fly ash. The focus on this research is on the improvement of engineering properties of two natural residual soils and mixed with different proportions of liquid chemical. Series of laboratory test on engineering properties, such as Modified Proctor Test, Consistency limits, moisture-density relationship (compaction) and California Bearing Ratio was undertaken to evaluate the effectiveness and performances of this chemical as soil stabilizing agent.
\end{abstract}

\section{INTRODUCTION}

\subsection{General}

Over the past few decades several factors have led to an increase in the number of people migrating to large cities. Consequently these large cities are getting over populated and quite expectedly necessity of business, residential construction has increased the civil engineering projects located in areas with unsuitable soil is one of the most common problems in many parts of the world. The unsuitable soil (Black cotton Soil) can be stabilized by performing soil stabilization. In India black soil is the most problematic soil when it comes to construction. In rainy season black cotton soil swells and become sticky. Whereas in summers the moisture present in the soil evaporates and soil shrinks resulting in the crack of approximate 10 to $15 \mathrm{~cm}$ wide and up to 1 meter deep. The percentage covered by black cotton soil in geotechnical areas of India is $16.6 \%$, which says huge amount of soil in India needs stabilization. Mechanical, chemical, electrical, thermal and other methods are in practice to improve the engineering properties of soil.

In developing countries like India the biggest handicap to provide a complete network of road system is the limited finances available to build road by the conventional methods. Therefore there is a need for low cost road construction to meet the growing needs of the road traffic. The construction cost can be considerably decreased by selecting local materials including local soils for the construction of the lower layers of the pavement such as the embankment and sub-base course. If the stability of the local soil is not adequate for supporting wheel loads, the properties are improved by soil stabilization techniques. Thus the principle of soil stabilized road construction involves the effective utilization of local soils and other suitable stabilizing agents.

\subsection{Project Undertaken}

The work presented in this paper is a contribution to the application of chemical and conventional stabilization techniques, by adding terrasil and river sand for two different soil i.e. red soil and black cotton soil. Initially, the chemical, physical and geotechnical properties of the untreated soils were determined. These tests were complemented by direct measurements of the properties of both the soil i.e. consistency limits, heavy compaction, specific gravity and California bearing ratio. Secondly, the study examined the effects of different types of stabilization on the physical properties of both the soils.

\section{MATERIAL AND METHODOLOGY}

\subsection{Introduction}

Soil has various meaning, depending upon the general professional field in which it is being considered in general soil mean the top layer of the earth surface in which plants can grow consisting of rocks and minerals particles mixed with decayed organic matter and having the capability of 
retaining water. And thus stabilizing soil gives better bearing capacity.

\subsection{Types of Soil}

\section{a. Black cotton soil}

In this study, the soil under scrutiny was gathered from the vicinity of Flora Institute Of Technology, Khopi, Pune. At first, so as to distinguish the wide soil sorts in the field with no research facility testing, a visual characterization is done, which demonstrates that soil under scrutiny is brown in shading, further examination is completed with water to make a paste and rubbed in middle of fingers leaves a stain which is not watched for residues. When it is wet it doesn't get to be dry soon. In like way, display swelling and shrinkage and are described by a typical shrinkage pattern. The soil has an expansive surface zone because of level and lengthened molecule shapes that stick together when wet, avoiding typical waste procedures. When it is wet it doesn't get to be dry soon. In like way, when completely dry, it is not soon wetted and shrinks causing breaks.

\section{b. Red soil}

Red soil is derived from weathering of ancient metamorphic rock of the Deccan plateau. Red soil is any of a group of soil that grow in a humid temperature, moist climate under deciduous and mix forests and that have raw mineral. Thin organic layers overlying a yellowish brown leached deposit resting on an alluvial. Their colour is mostly ferric oxides occurring a slight coatings on the soil particle through the iron oxide arise as hematite as hydrous ferric oxide, the colour is red and when it happen in the hydrate system as limonite the soil become to be yellow colour. Generally the surface soils are red while the horizon under gets yellowish colour.

\section{c. River sand}

Sand is natural occurring granular material composed of finely divided rock \& mineral particles. It is defined by size, being finer than gravel \& coarser than silt. Sand can also refer toward textural class of soil or soil type that is a soil containing more than $85 \%$ sand size particles (by mass).

The composition of sand varies, depending on the local rock sources and conditions, but the most common constituent of sand in inland continental settings and non-tropical coastal settings is silica (silicon dioxide, or $\mathrm{SiO} 2$ ), usually in the form of quartz. The second most common type of sand is calcium carbonate, for example aragonite, which has mostly been created, over the past half billion years, by various forms of life, like coral and shellfish. It is, for example, the primary form of sand apparent in areas where reefs have dominated the ecosystem for millions of years like the Caribbean.

\subsection{Tests On Soil}

Test to know the engineering properties of soil can be carried out on site as well laboratory. On-site test are as follows:

1.Standard Penetration Test.

2.Cone Penetration Test, etc.

\author{
laboratory test are as follows: \\ 1. Atterberg Limits Test. \\ 2. California Bearing Ratio. \\ 3. Direct Shear Test. \\ 4. Expansion Index Test. \\ 5. Soil Compaction Test. \\ 6. Unconfined Compression Test etc.
}

\subsection{Types of stabilization}

1. Mechanical stabilization

2. Lime stabilization.

3. Cement stabilization.

4. Lime-fly ash stabilization.

5. Using Bitumen.

6. Other chemicals like Stabling, RBI-81, Soil fix and Zydex etc.

\subsection{Type of Chemical}

a. Terrasil

Terrasil is nanotechnology based 100 percent organo silane, water dissolvable, bright and warmth steady, receptive soil modifier to waterproof soil subgrade. The Characteristics of Terrasil is such that it wipes out narrow ascent and water entrance from top, decreases water penetrability of soil bases $(10-5 \mathrm{~cm} / \mathrm{s}$ to $10-7 \mathrm{~cm} / \mathrm{s})$ while keeping up $100 \%$ vapor porousness, diminishes expansively and free swell, keeps up dry CBR under wet conditions, holds quality of road bases and expands imperviousness to deformation by keeping up frictional values between residue and controls disintegration of soils . TERRASIL is anything but difficult to utilize and safe to handle item that renders treated soils very water repellant. Terrasil conveys demonstrated results with a wide range of soils and doesn't modify their appearance. Terrasil is a think that blends with water. Once connected, it attempts to bond with the soil's silica and oxygen atoms. This implanted synthetic response makes the treated soil $98 \%$ water safe. The holding procedure starts inside of 3 hours of the beginning application till the procedure is finished ( $72 \mathrm{hrs}$.), Terrasil turns into a changeless piece of every soil particle and won't separate or filter into groundwater . 
Table 1 Chemical composition of terrasil.

\begin{tabular}{|l|l|}
\hline Chemical Compound & Value in Range(\%) \\
\hline Hydroxyalkyl-alkoxy-alkylsilyl & $65-70 \%$ \\
\hline Benzyl Alcohol & $25-27 \%$ \\
\hline Ethylene Glycol & $3-5 \%$ \\
\hline
\end{tabular}

\subsection{Engineering Property of Soil}

Table 2 General properties of soil.

\begin{tabular}{|l|l|l|}
\hline Properties & Black cotton soil & Red soil \\
\hline Liquid limit & $75 \%$ & $41 \%$ \\
\hline Plastic limits & $35 \%$ & $20.15 \%$ \\
\hline Plasticity index & 40 & $19.85 \%$ \\
\hline Free swelling index & $17.50 \%$ & 0 \\
\hline Specific gravity & 2.51 & 2.64 \\
\hline Dry density gm/cc & 1.34 & 1.775 \\
\hline Moisture content & $25.54 \%$ & $15 \%$ \\
\hline
\end{tabular}

\section{LABORATORY WORK}

\subsection{General}

Performed various laboratory test on soil i.e Red and Black cotton soil to find out their basic properties such as liquid limit, plastic limit, specific gravity, modified proctor \& CBR tests.And soil stabilization by using conventional stabilisation for both red and black cotton soil by using natural river sand $(10 \%) \&$ chemical stabilisation for both red \&

Red soil

Liquid limit black cotton soil by using Terrasil(0.041\%) from Zydex Industries.

\subsection{Conventional Method Engineering Properties}

In conventional method $10 \%$ of natural river sand is used as an additives to the soil i.e. both red and black cotton soil by weight of soil. All the test such as liquid limit, plastic limit, specific gravity, modified proctor \& C.B.R test were performed on respective soils.

Table 3 LL of Red soil with $10 \%$ sand.

\begin{tabular}{|l|l|l|l|}
\hline No & I & II & III \\
\hline No. Of blows & 24 & 25.5 & 28 \\
\hline Container no & 1 & 2 & 3 \\
\hline Mass of container + wet soil $(\mathrm{g})$ & 25 & 33 & 27 \\
\hline Mass of container + dry soil $(\mathrm{g})$ & 22.5 & 28.5 & 24 \\
\hline Mass of water $(\mathrm{g})$ & 2.5 & 4.5 & 3 \\
\hline Mass of container $(\mathrm{g})\left(\mathrm{W}_{1}\right)$ & 16 & 16 & 16 \\
\hline Mass of oven dry soil $(\mathrm{g})\left(\mathrm{W}_{2}\right)$ & 6.5 & 12.5 & 8 \\
\hline Water content $(\%)$ & 38.46 & 36 & 37.5 \\
\hline
\end{tabular}

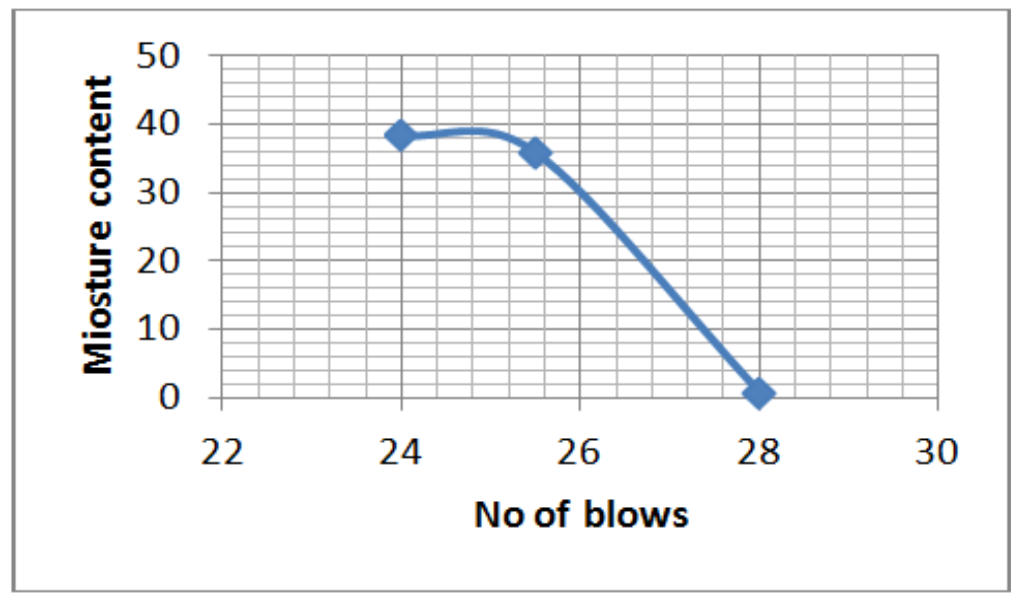

Fig. 1 Flow curve for Red Soil with 10\% sand. 


\section{Liquid Limit:- 38.5}

Plastic limit

Table 4 PL of Red soil with $10 \%$ sand.

\begin{tabular}{|l|l|l|l|}
\hline No & I & II & III \\
\hline CONTAINER NO & 1 & 2 & 3 \\
\hline Wt of container & 16.5 & 16.5 & 16.5 \\
\hline Wt of cont+ wet of soil & 23.5 & 22 & 22.6 \\
\hline Wt of cont. + dry soil & 21 & 20.5 & 20 \\
\hline Wt of water & 2.5 & 1.5 & 2.6 \\
\hline Wt of dry soil & 7 & 6 & 6.5 \\
\hline Water content & 35 & 25 & 40 \\
\hline
\end{tabular}

Plastic Limit:-33.33

\section{Specific gravity [IS: 2720 (Part-III/SEC-I)]}

Table 5 Specific Gravity Test for Red soil with $10 \%$ sand.

\begin{tabular}{|l|l|l|l|}
\hline Determination & I & II & III \\
\hline Density bottle no & $1(250 \mathrm{gm})$ & $2(350 \mathrm{gm})$ & $3(300 \mathrm{gm})$ \\
\hline Mass of density bottle & 681 & 681 & 681 \\
\hline Mass of density bottle + dry soil & 932 & 1032 & 982 \\
\hline Mass of density bottle + soil + water & 1653 & 1684 & 1668 \\
\hline Mass of bottle +water & 1506 & 1506 & 1506 \\
\hline Specific gravity & 2.41 & 2.02 & 2 \\
\hline
\end{tabular}

\section{Average Specific Gravity=2.14}

\section{Modified proctor test (Heavy Compaction)}

Table 6 Proctor Test for Red soil with $10 \%$ sand.

\begin{tabular}{|l|l|l|l|l|l|}
\hline Determination no & I & II & III & IV & V \\
\hline Wt of mould + compacted soil & 5136 & 9096 & 10560 & 10120 & 9560 \\
\hline Wt of mould & 5546 & 5546 & 5546 & 5546 & 5546 \\
\hline Volume of mould & 2250 & 2250 & 2250 & 2250 & 2250 \\
\hline Wt of compacted soil & 2567 & 3550 & 5014 & 4574 & 4014 \\
\hline bulk density & 1.4 & 1.57 & 1.80 & 2.032 & 1.784 \\
\hline Dry density & 1.29 & 1.42 & 1.56 & 1.722 & 1.48 \\
\hline Percentage of water use & 6 & 10 & 15 & 18 & 20 \\
\hline
\end{tabular}

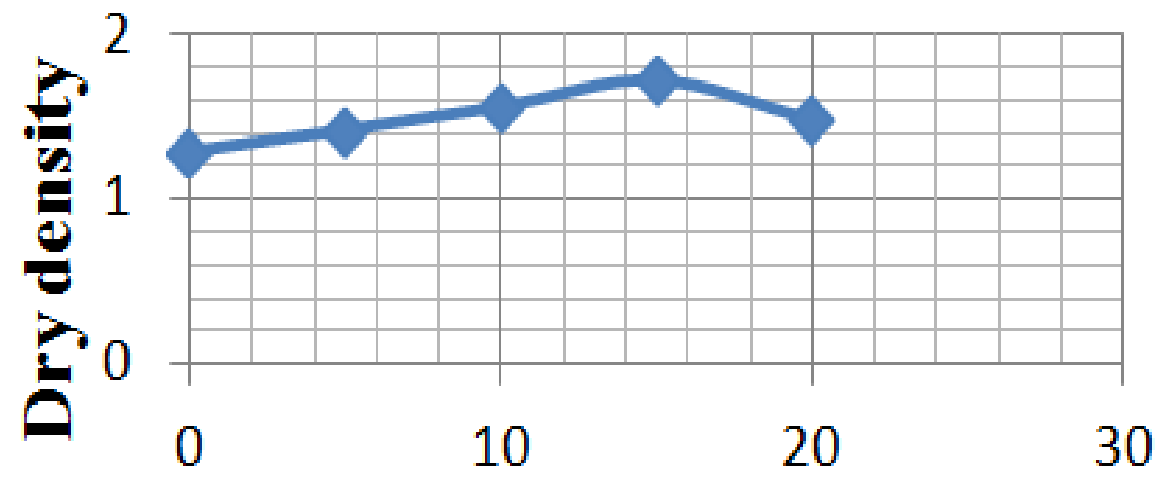

Fig. 2 Compaction Curve for Red soil with $10 \%$ sand. 
OMC: $-15 \%$ and MDD:- $1.7125 \mathrm{~g} / \mathrm{cm}^{3}$

CBR

Table 7 Standard load used in C.B.R test.

\begin{tabular}{|l|l|l|}
\hline Penetration & Unit std. Load $(\mathbf{k g f} / \mathbf{c m} 2)$ & Total std. Load $(\mathbf{k g f})$ \\
\hline $2.5 \mathrm{~mm}$ & 70 & 1370 \\
\hline $5 \mathrm{~mm}$ & 105 & 2055 \\
\hline $7.5 \mathrm{~mm}$ & 134 & 2630 \\
\hline $10 \mathrm{~mm}$ & 162 & 3180 \\
\hline $12.5 \mathrm{~mm}$ & 183 & 3600 \\
\hline
\end{tabular}

Table 8 C.B.R test of red soil with $10 \%$ sand.

\begin{tabular}{|c|c|c|c|}
\hline Soil type & Penetration & \multicolumn{2}{|c|}{ CBR } \\
\hline \multirow{2}{*}{ Red soil } & & Native & 10\% sand \\
& @ $2.5 \mathrm{~mm}$ & 6.5 & 8.37 \\
\cline { 2 - 4 } & $@ 5.0 \mathrm{~mm}$ & 7.99 & 9.47 \\
\hline
\end{tabular}

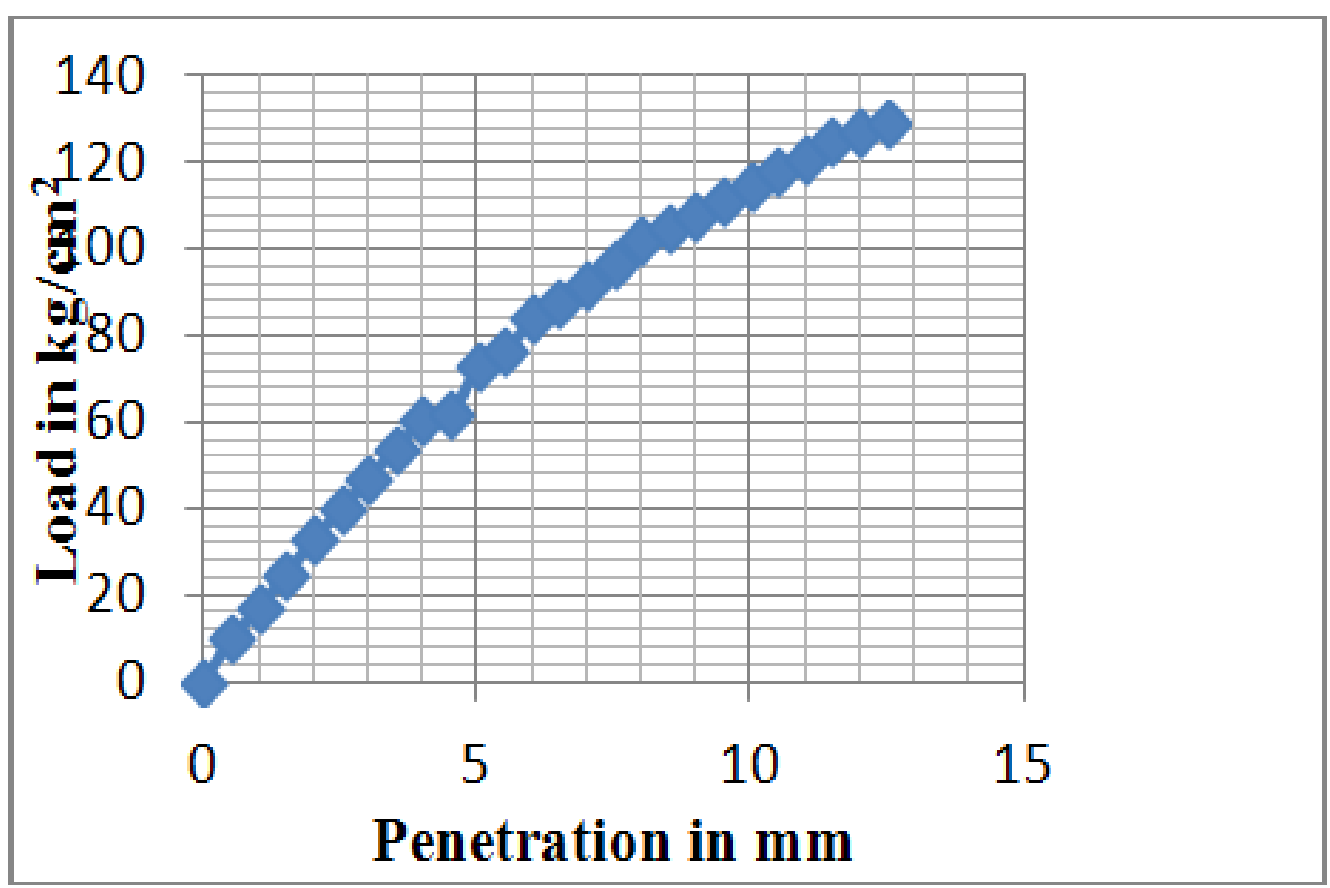

Fig. 3 Load Penetration Curve for C.B.R test of Red soil with 10\% Sand

Black cotton soil

Liquid limit

Table 9 LL B.C soil with $10 \%$ sand.

\begin{tabular}{|l|l|l|l|}
\hline N0 & I & II & III \\
\hline No. Of blows & 21 & 26 & 31 \\
\hline Container no & 1 & 2 & 3 \\
\hline Mass of container + wet soil $(\mathrm{g})$ & 26 & 27.5 & 27 \\
\hline Mass of container + dry soil $(\mathrm{g})$ & 22.5 & 23.5 & 23 \\
\hline Mass of water $(\mathrm{g})$ & 3.5 & 4 & 4 \\
\hline Mass of container $(\mathrm{g})\left(\mathrm{W}_{1}\right)$ & 16.5 & 16.5 & 16.5 \\
\hline Mass of oven dry soil $(\mathrm{g})\left(\mathrm{W}_{2}\right)$ & 6 & 6 & 6.5 \\
\hline Water content $(\%)$ & 58.3 & 61.63 & 66.66 \\
\hline
\end{tabular}




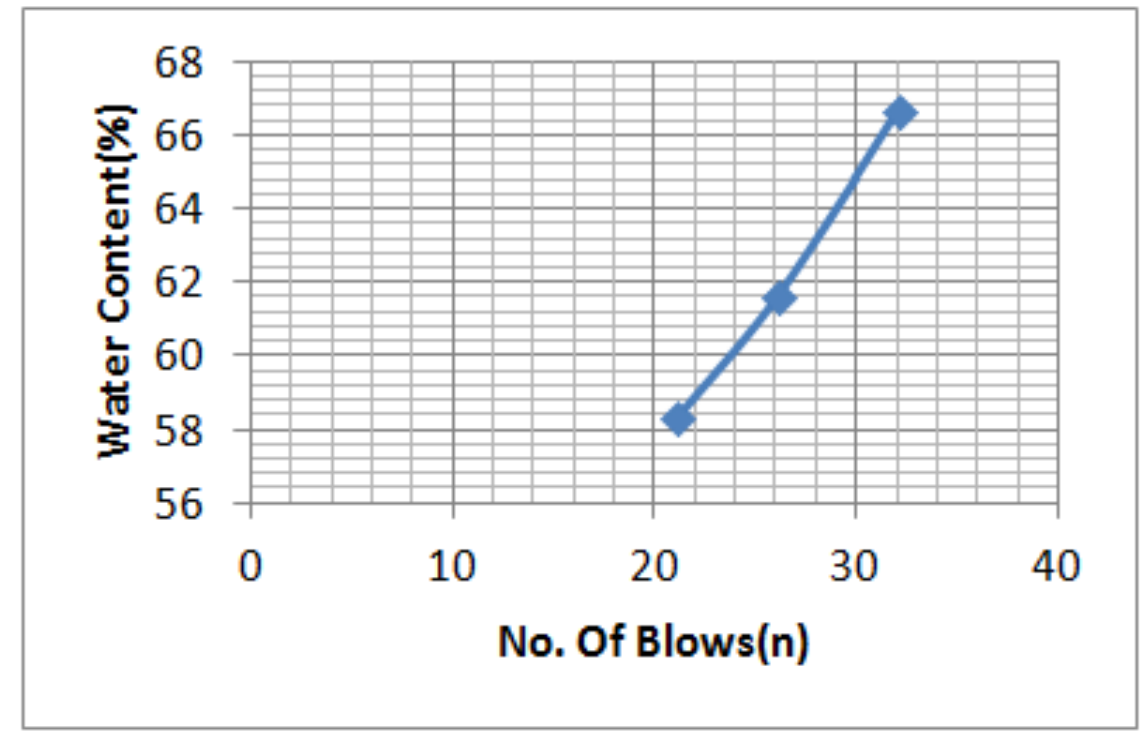

Fig. 4 Flow curve for B.C soil with $10 \%$ sand.

Liquid Limit:-60.9

Plastic limit

Table 10 PL for B.C soil with $10 \%$ sand.

\begin{tabular}{|l|l|l|l|}
\hline NO & I & II & III \\
\hline CONTAINER NO & 1 & 2 & 3 \\
\hline Wt of container & 16.5 & 16.5 & 16.5 \\
\hline Wt of cont+ wet of soil & 24.5 & 23.5 & 23 \\
\hline Wt of cont. + dry soil & 23 & 22 & 21.5 \\
\hline Wt of water & 1.5 & 1.5 & 1.5 \\
\hline Wt of dry soil & 8 & 7 & 7.5 \\
\hline Water content & 18.75 & 21.14 & 20 \\
\hline
\end{tabular}

Plastic Limit:- 19.96

Specific gravity [IS: 2720 (Part-III/SEC-I)]

Table 11 Specific gravity test for B.C soil with $10 \%$ sand.

\begin{tabular}{|l|l|l|l|}
\hline Determination & I & II & III \\
\hline Density bottle no & 1 & 2 & 3 \\
\hline Mass of density bottle & 681 & 681 & 681 \\
\hline Mass of density bottle + dry soil & 932 & 1033 & 980 \\
\hline Mass of density bottle + soil + water & 1640 & 1714 & 1677 \\
\hline Mass of bottle +water & 1506 & 1506 & 1506 \\
\hline Specific gravity & 2.14 & 2.44 & 2.33 \\
\hline
\end{tabular}

Average Specific Gravity:-2.30

Modified proctor test(Heavy Compaction)

Table 12 Proctor Test for B.C soil with $10 \%$ of Sand.

\begin{tabular}{|l|l|l|l|l|}
\hline Determination no & I & II & III & IV \\
\hline Wt of mould + compacted soil & 8966 & 9331 & 9790 & 9565 \\
\hline Wt of mould & 5546 & 5546 & 5546 & 5546 \\
\hline Volume of mould & 2250 & 2250 & 2250 & 2250 \\
\hline Wt of compacted soil & 3420 & 3785 & 4244 & 5546 \\
\hline bulk density & 1.52 & 1.68 & 1.88 & 1.78 \\
\hline Dry density & 1.43 & 1.55 & 1.70 & 1.56 \\
\hline Percentage of water use & 6 & 8 & 10 & 13 \\
\hline
\end{tabular}




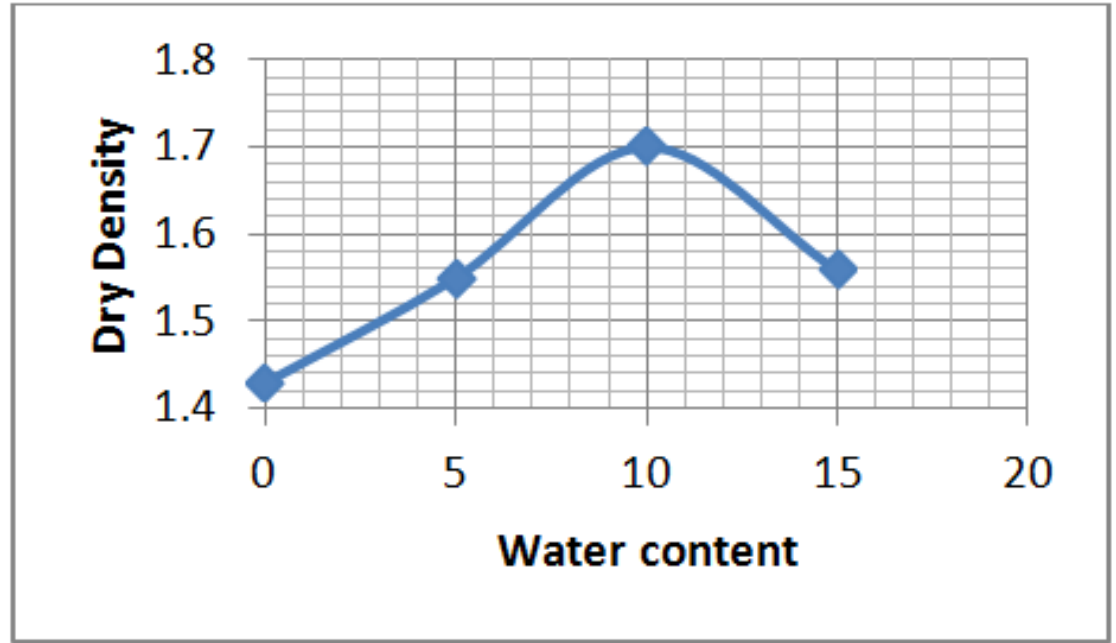

Fig. 5 Compaction Curve for B.C soil with 10\% Sand.

OMC:- 10.125\% and MDD:- $1.7 \mathrm{~g} / \mathrm{cm}^{3}$

CBR

Table13 Standard load used in C.B.R test.

\begin{tabular}{|l|l|l|}
\hline Penetration & Unit std. Load $(\mathbf{k g f} / \mathbf{c m} 2)$ & Total std. Load $(\mathbf{k g f})$ \\
\hline $2.5 \mathrm{~mm}$ & 70 & 1370 \\
\hline $5 \mathrm{~mm}$ & 105 & 2055 \\
\hline $7.5 \mathrm{~mm}$ & 134 & 2630 \\
\hline $10 \mathrm{~mm}$ & 162 & 3180 \\
\hline $12.5 \mathrm{~mm}$ & 183 & 3600 \\
\hline
\end{tabular}

Table 14 C.B.R Test for B.C Soil with $10 \%$ sand.

\begin{tabular}{|l|l|l|l|}
\hline \multirow{2}{*}{ Soil type } & Penetration & \multicolumn{2}{|c|}{ CBR } \\
\cline { 3 - 4 } & & Native & $\mathbf{1 0 \%}$ Sand \\
\hline Black cotton soil & $@ 2.5 \mathrm{~mm}$ & 1.64 & 2.05 \\
\cline { 2 - 4 } & $@ 5.0 \mathrm{~mm}$ & 1.42 & 1.8 \\
\hline
\end{tabular}

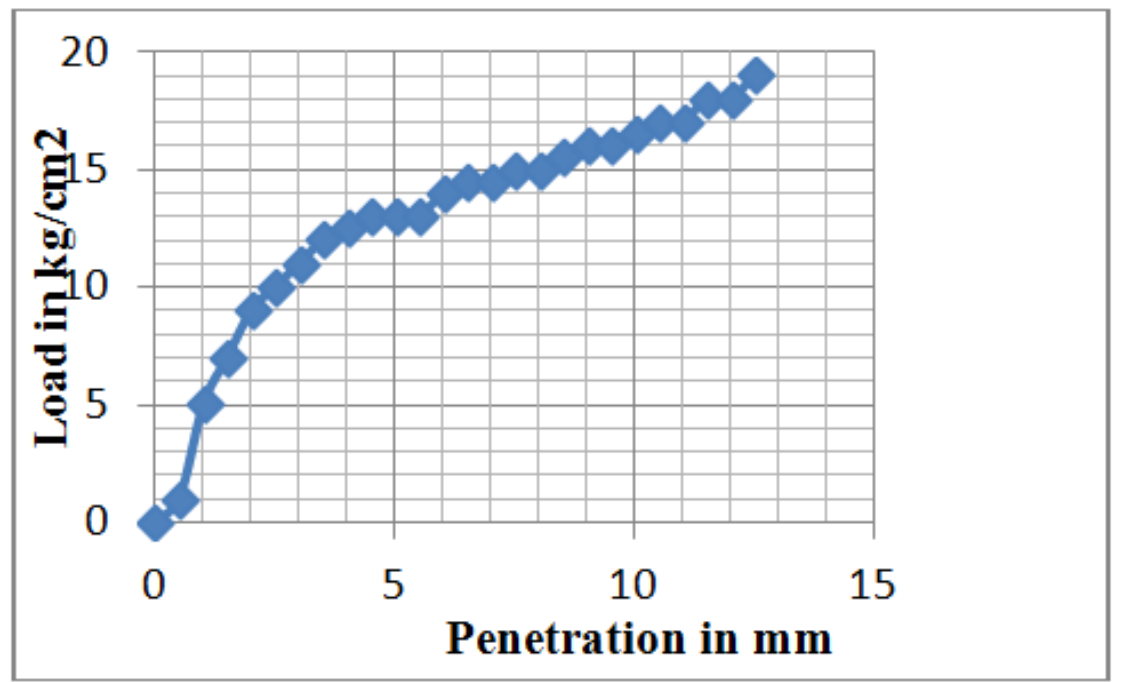

Fig. 6 Load Penetration Curve for C.B.R Test of B.C soil with 10\% sand.

4.3 Chemical Method Engineering Properties In chemical method $0.041 \%$ of Terrasil is used as an additive to the red \& black cotton soil by weight of soil. All the test such as liquid limit, plastic limit, specific gravity, modified proctor \& C.B.R test were performed on respective soils. 
Red soil

Liquid limit

Table 15 LL Red soil With $0.041 \%$ Terrasil.

\begin{tabular}{|l|l|l|l|}
\hline N0 & I & II & III \\
\hline No. Of blows & 25 & 28 & 23 \\
\hline Container no & 1 & 2 & 3 \\
\hline Mass of container + wet soil $(\mathrm{g})$ & 26 & 28 & 30 \\
\hline Mass of container + dry soil $(\mathrm{g})$ & 25 & 26.5 & 29 \\
\hline Mass of water $(\mathrm{g})$ & 1 & 1.5 & 1 \\
\hline Mass of container $(\mathrm{g})\left(\mathrm{W}_{1}\right)$ & 16.5 & 16.5 & 16.5 \\
\hline Mass of oven dry soil $(\mathrm{g})\left(\mathrm{W}_{2}\right)$ & 8.5 & 10 & 12.5 \\
\hline Water content $(\%)$ & 11.76 & 15 & 8 \\
\hline
\end{tabular}

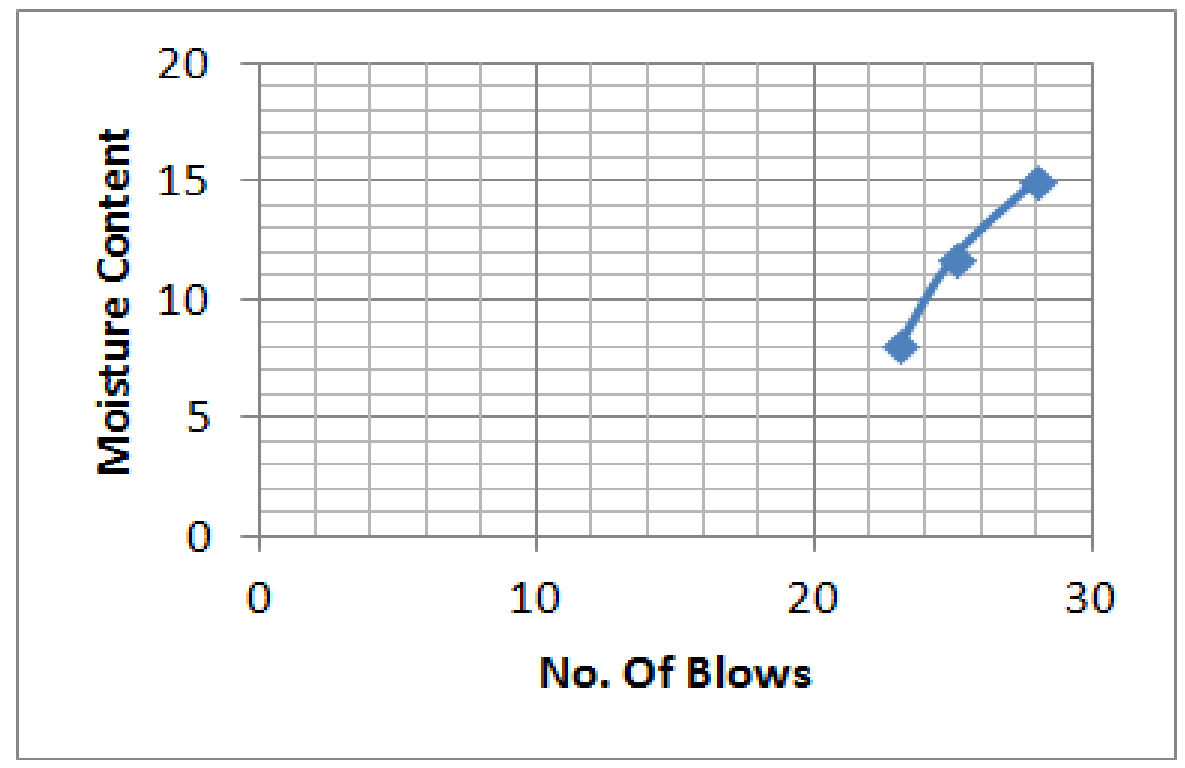

\section{Liquid Limit:-11.7}

Fig. 7 Flow curve for Red Soil with $0.041 \%$ Terrasil.

\section{Plastic limit}

Table 16 Plastic Limit of Red Soil with $0.041 \%$ Terrasil.

\begin{tabular}{|l|l|l|l|}
\hline NO & I & II & III \\
\hline CONTAINER NO & 1 & 2 & 3 \\
\hline Wt of container & 16.5 & 16.5 & 16.5 \\
\hline Wt of cont+ wet of soil & 33.5 & 32.5 & 31.2 \\
\hline Wt of cont. + dry soil & 30 & 29.5 & 28 \\
\hline Wt of water & 3.5 & 3 & 3.2 \\
\hline Wt of dry soil & 13.5 & 13 & 11.5 \\
\hline Water content & 25.9 & 23.07 & 27.8 \\
\hline
\end{tabular}

Plastic Limit:-25.59

Modified proctor test(Heavy Compaction)

Table 17 Proctor Test Compaction Test of Red soil with $0.041 \%$ Terrasil

\begin{tabular}{|l|l|l|l|l|l|}
\hline Determination no & I & II & III & IV & V \\
\hline Wt of mould + compacted soil & 7707 & 8446 & 9458 & 8458 & 5671 \\
\hline Wt of mould & 5546 & 5546 & 5546 & 5546 & 5546 \\
\hline Volume of mould & 2250 & 2250 & 2250 & 2250 & 2250 \\
\hline Wt of compacted soil & 2161 & 2900 & 3912 & 3125 & 2912 \\
\hline bulk density & 0.96 & 1.28 & 1.73 & 1.38 & 1.29 \\
\hline Dry density & 0.91 & 1.16 & 1.50 & 1.16 & 1.075 \\
\hline Percentage of water use & 6 & 10 & 15 & 18 & 20 \\
\hline
\end{tabular}




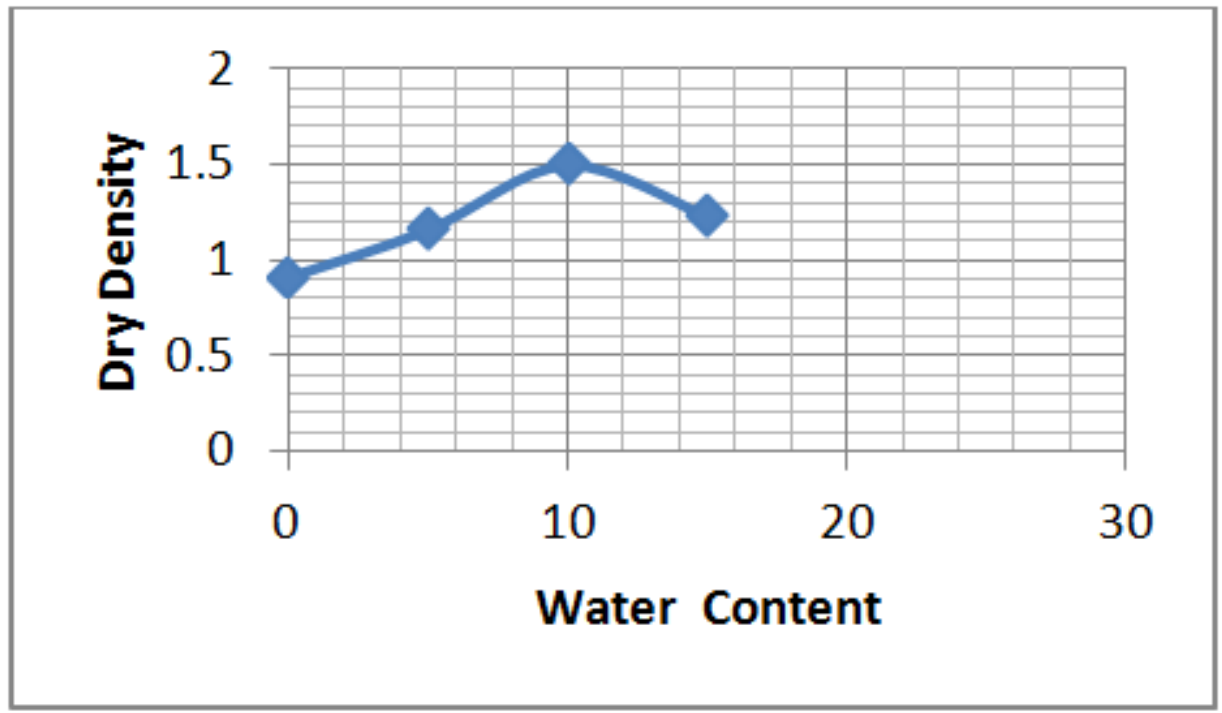

Fig. 8 Compaction Curve for Red Soil with $0.041 \%$ Terrasil.

OMC:-10.18\% and MDD:-1.91g/ $\mathrm{cm}^{3}$

\section{CBR}

Table 18 Standard Load used in C.B.R Test.

\begin{tabular}{|l|l|l|}
\hline Penetration & $\begin{array}{l}\text { Unit std. Load } \\
\text { (kgf/cm2) }\end{array}$ & $\begin{array}{l}\text { Total std. Load } \\
\text { (kgf) }\end{array}$ \\
\hline $2.5 \mathrm{~mm}$ & 70 & 1370 \\
\hline $5 \mathrm{~mm}$ & 105 & 2055 \\
\hline $7.5 \mathrm{~mm}$ & 134 & 2630 \\
\hline $10 \mathrm{~mm}$ & 162 & 3180 \\
\hline $12.5 \mathrm{~mm}$ & 183 & 3600 \\
\hline
\end{tabular}

Table 19 C.B.R test of Red soil with $0.041 \%$ Terrasil.

\begin{tabular}{|l|l|l|l|}
\hline \multirow{2}{*}{ Soil Type } & \multirow{2}{*}{ Penetration } & \multicolumn{2}{c|}{ C.B.R } \\
\cline { 3 - 4 } & & Native & 0.041\% Terrasil \\
\hline \multirow{2}{*}{ Red Soil } & $@ 2.5 \mathrm{~mm}$ & 1.64 & 2.79 \\
\cline { 2 - 4 } & $@ 5 \mathrm{~mm}$ & 1.42 & 2.46 \\
\hline
\end{tabular}

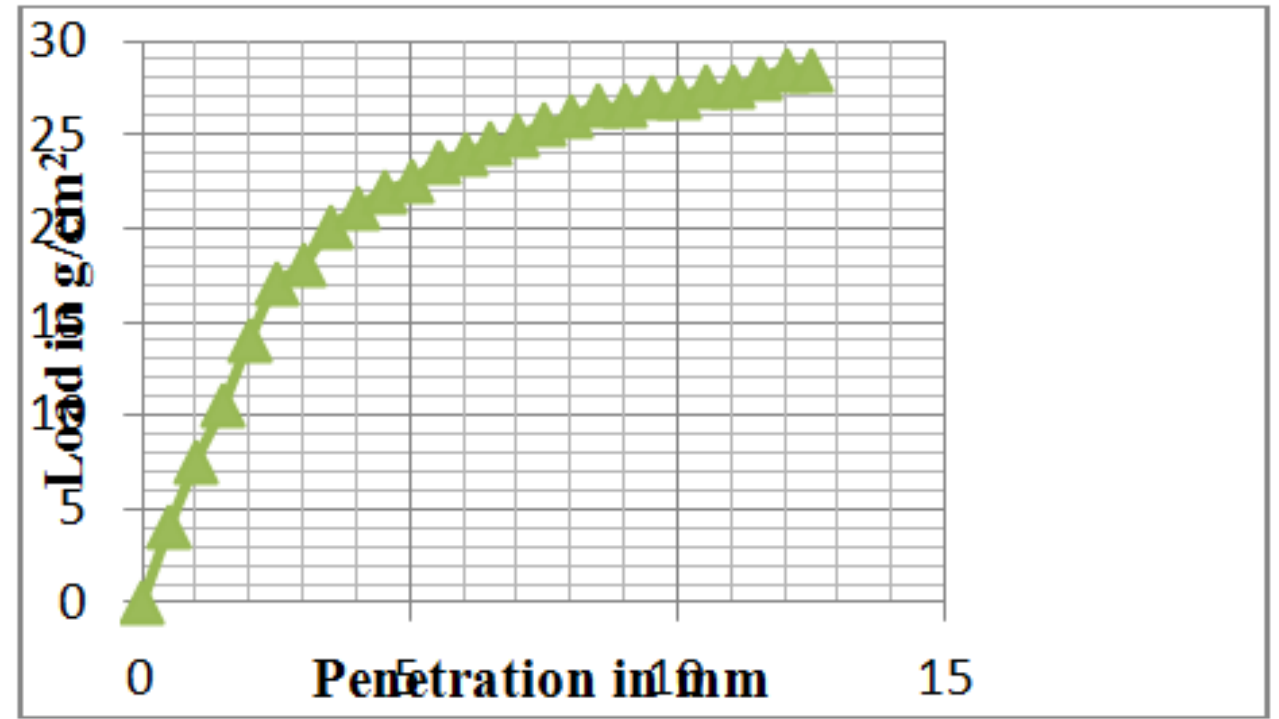

Fig. 9 Load Penetration Curve for C.B.R Test of Red soil with 0.041\% Terrasil. 
Black cotton soil

Liquid limit

Table 20 LL B.C Soil with $0.041 \%$ Terrasil.

\begin{tabular}{|l|l|l|l|}
\hline N0 & I & II & III \\
\hline No. Of blows & 25 & 22 & 28 \\
\hline Container no & 1 & 2 & 3 \\
\hline Mass of container + wet soil $(\mathrm{g})$ & 29 & 32 & 26 \\
\hline Mass of container + dry soil $(\mathrm{g})$ & 25 & 26.5 & 23 \\
\hline Mass of water $(\mathrm{g})$ & 4 & 5.5 & 3 \\
\hline Mass of container $(\mathrm{g})\left(\mathrm{W}_{1}\right)$ & 16.5 & 16.5 & 16.5 \\
\hline Mass of oven dry soil $(\mathrm{g})\left(\mathrm{W}_{2}\right)$ & 8.5 & 10 & 6.5 \\
\hline Water content $(\%)$ & 47 & 55 & 46 \\
\hline
\end{tabular}

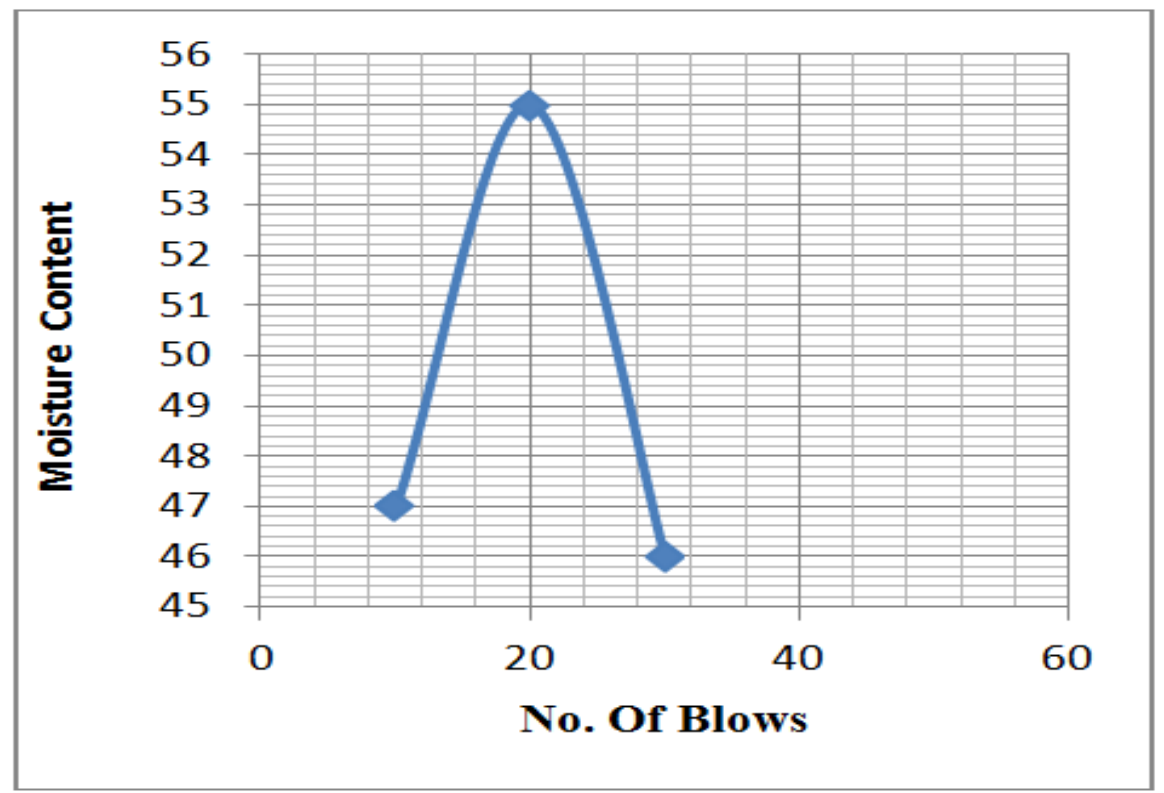

Liquid Limit:- 51.14

Fig. 10 Flow Curve for B.C soil with 0.041\% Terrasil. Plastic limit

Table 21 PL B.C soil with $0.041 \%$ Terrasil.

\begin{tabular}{|l|l|l|l|}
\hline NO & I & II & III \\
\hline CONTAINER NO & 1 & 2 & 3 \\
\hline Wt of container & 16.5 & 16.5 & 16.5 \\
\hline Wt of cont+ wet of soil & 25 & 26 & 26.5 \\
\hline Wt of cont. + dry soil & 23.5 & 24.5 & 24.3 \\
\hline Wt of water & 1.5 & 1.5 & 1.5 \\
\hline Wt of dry soil & 7 & 8 & 6.3 \\
\hline Water content & 21.42 & -18.75 & 23.80 \\
\hline
\end{tabular}

Plastic Limit:-21.32

\section{Modified proctor test(Heavy Compaction)}

Table 22 Compaction Test of B.C soil with $0.041 \%$ Terrasil.

\begin{tabular}{|l|l|l|l|l|}
\hline Determination no & I & II & III & IV \\
\hline Wt of mould + compacted soil & 9543 & 9728 & 9941 & 9812 \\
\hline Wt of mould & 5546 & 5546 & 5546 & 5546 \\
\hline Volume of mould & 2250 & 2250 & 2250 & 2250 \\
\hline Wt of compacted soil & 3997 & 4182 & 4395 & 4266 \\
\hline bulk density & 1.77 & 1.85 & 1.95 & 1.89 \\
\hline Dry density & 1.63 & 1.68 & 1.69 & 1.61 \\
\hline Percentage of water use & 8 & 10 & 15 & 17 \\
\hline
\end{tabular}




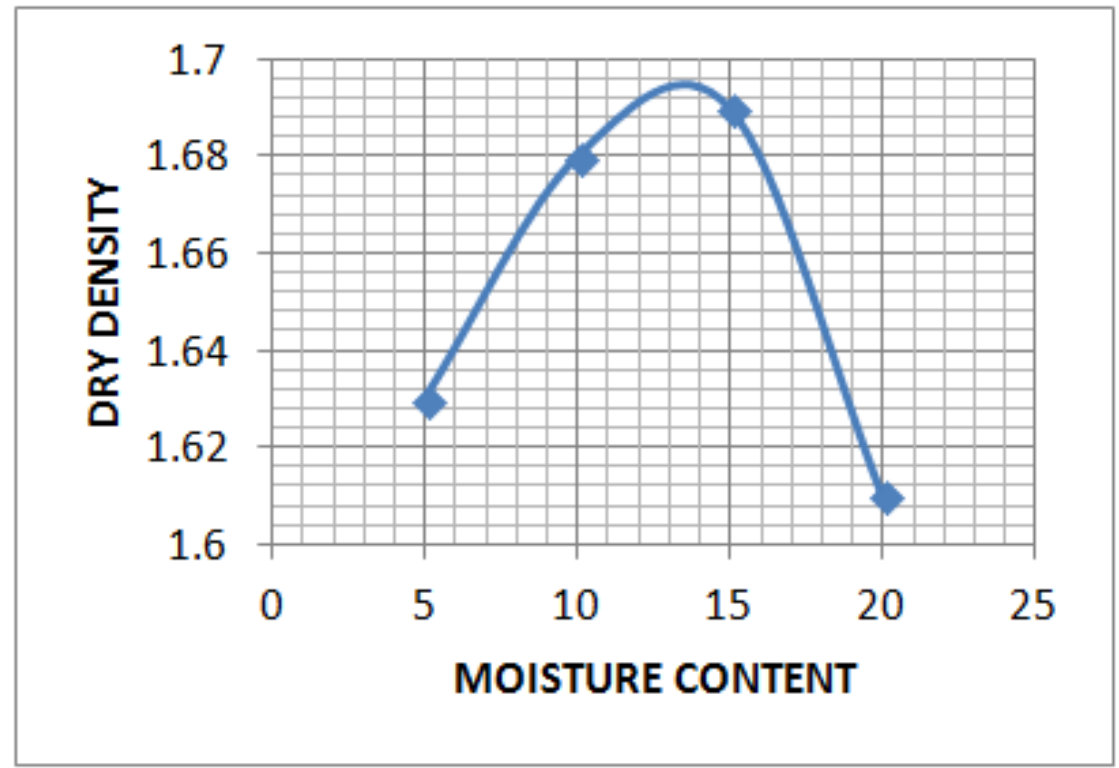

Fig. 11 Compaction Curve of B.C soil with $0.041 \%$ of Terrasil.

\section{OMC:- 14.5 and MDD:-1.692}

\section{CBR}

Table 23 Standard Load Used in C.B.R Test.

\begin{tabular}{|l|l|l|}
\hline Penetration & $\begin{array}{l}\text { Unit std. Load } \\
\text { (kgf/cm2) }\end{array}$ & $\begin{array}{l}\text { Total std. Load } \\
\text { (kgf) }\end{array}$ \\
\hline $2.5 \mathrm{~mm}$ & 70 & 1370 \\
\hline $5 \mathrm{~mm}$ & 105 & 2055 \\
\hline $7.5 \mathrm{~mm}$ & 134 & 2630 \\
\hline $10 \mathrm{~mm}$ & 162 & 3180 \\
\hline $12.5 \mathrm{~mm}$ & 183 & 3600 \\
\hline
\end{tabular}

Table 24 C.B.R test of B.C soil with $0.041 \%$ Terrasil.

\begin{tabular}{|c|l|c|c|}
\hline Soil Type & Penetration & \multicolumn{2}{|c|}{ C.B.R } \\
\cline { 3 - 4 } & & Native & 0.041\% Terrasil \\
\hline $\begin{array}{c}\text { Black Cotton } \\
\text { Soil }\end{array}$ & $@ 2.5 \mathrm{~mm}$ & 1.64 & 10.641 \\
\cline { 2 - 4 } & $@ 5 \mathrm{~mm}$ & 1.42 & 20.175 \\
\hline
\end{tabular}

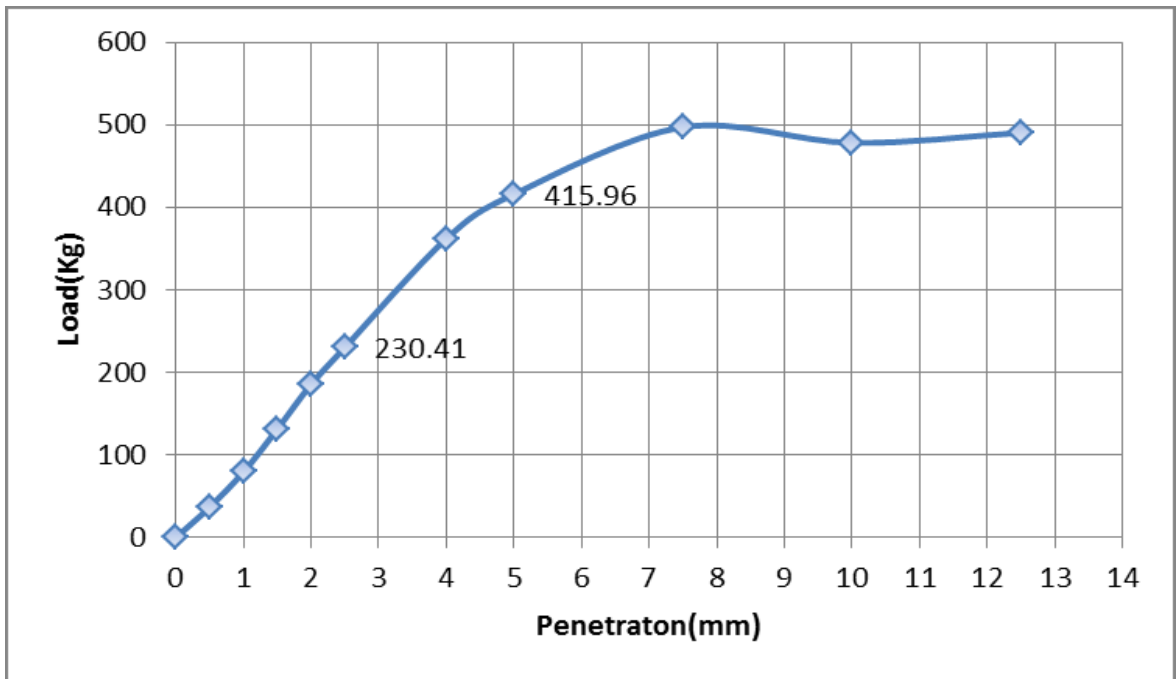

Fig. 12 Compaction Curve of B.C soil with $0.041 \%$ of Terrasil 


\section{RESULTS AND DISCUSSION}

\subsection{General}

This chapter includes the comparison between conventional and chemical stabilisation for both

\subsection{Red Soil}

\section{Liquid limit}

Table 25 Comparison Between Conventional \& Chemically Treated Red soil For LL.

\begin{tabular}{|l|l|}
\hline Red soil & $\begin{array}{l}\text { Liquid } \\
\text { limit }\end{array}$ \\
\hline Conventional & $38.5 \%$ \\
\hline Chemical & $11.7 \%$ \\
\hline
\end{tabular}

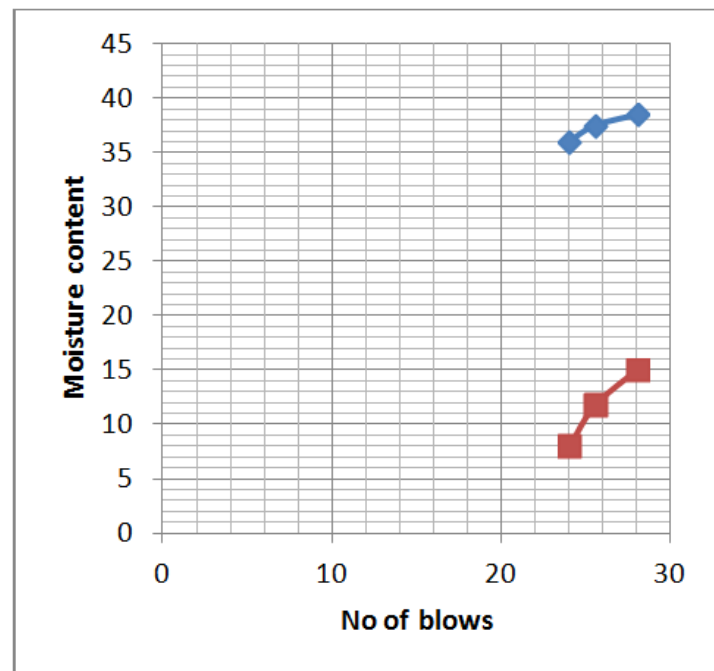

Fig. 13 Comparison Of Flow Curves Between Conventional \& Chemically Treated Red soil For LL.

\section{Plastic limit}

Table 26 Comparison Between Conventional \& Chemically Treated Red soil For PL.

\begin{tabular}{|l|l|}
\hline Red soil & $\begin{array}{l}\text { Plastic } \\
\text { limit }\end{array}$ \\
\hline Conventional & $33.5 \%$ \\
\hline Chemical & $25.59 \%$ \\
\hline
\end{tabular}

\section{Modified proctor test (Heavy Compaction)}

Table 27 Comparison Between Conventional \& Chemically Treated Red soil For Proctor Test.

\begin{tabular}{|l|l|l|}
\hline Red soil & OMC & MDD \\
\hline Conventional & $15.5 \%$ & $\begin{array}{l}1.17 \\
\mathrm{gm} / \mathrm{cm}^{3}\end{array}$ \\
\hline Chemical & $10.18 \%$ & $\begin{array}{l}1.91 \\
\mathrm{gm} / \mathrm{cm}^{3}\end{array}$ \\
\hline
\end{tabular}

red and black cotton soil and all the comparison are shown in the form of tables and graph.

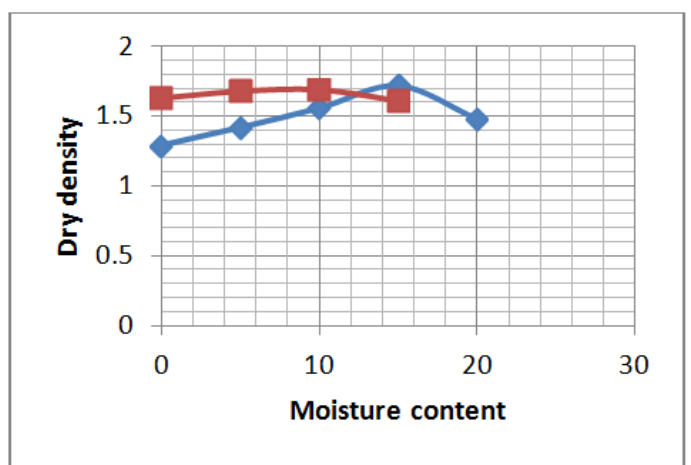

Fig. 14 Comparison of Compaction Curves between Conventional \& Chemically Treated Red

CBR soil for Proctor Test.

Table 28 Comparison Between Conventional \& Chemically Treated Red soil For C.B.R.

\begin{tabular}{|l|c|}
\hline Red soil & C.B.R \\
\hline Conventional & \\
\hline$@ 2.5 m m$ & $8.37 \%$ \\
\hline$@ 5 \mathbf{m m}$ & $9.47 \%$ \\
\hline Chemical & C.B.R \\
\hline$@ 2.5 m m$ & $16.1 \%$ \\
\hline$@ 5 \mathbf{m m}$ & $21.6 \%$ \\
\hline
\end{tabular}

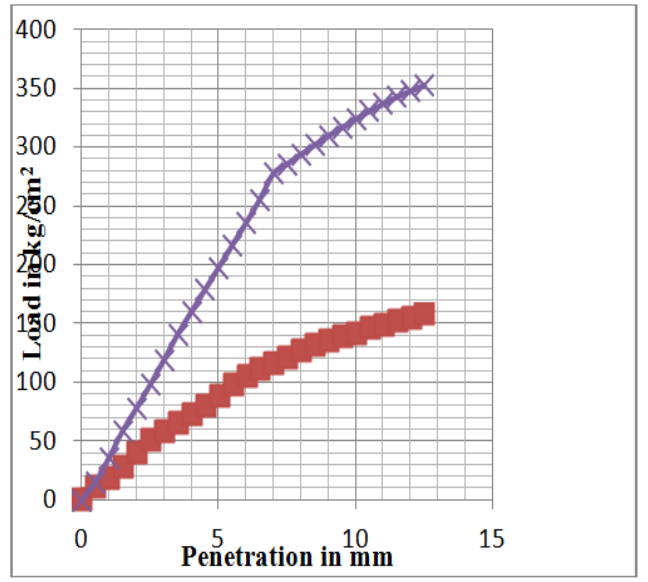

Fig. 15 Comparison of Load Penetration Curves between Conventional \& Chemically Treated Red soil For C.B.R.

\section{Black Cotton Soil}

\section{Liquid limit}

Table 29 Comparison Between Conventional \& Chemically Treated B.C soil For LL.

\begin{tabular}{|l|l|}
\hline $\begin{array}{l}\text { Black cotton } \\
\text { soil }\end{array}$ & $\begin{array}{l}\text { Liquid } \\
\text { limit }\end{array}$ \\
\hline Conventional & $66.56 \%$ \\
\hline Chemical & $51.5 \%$ \\
\hline
\end{tabular}




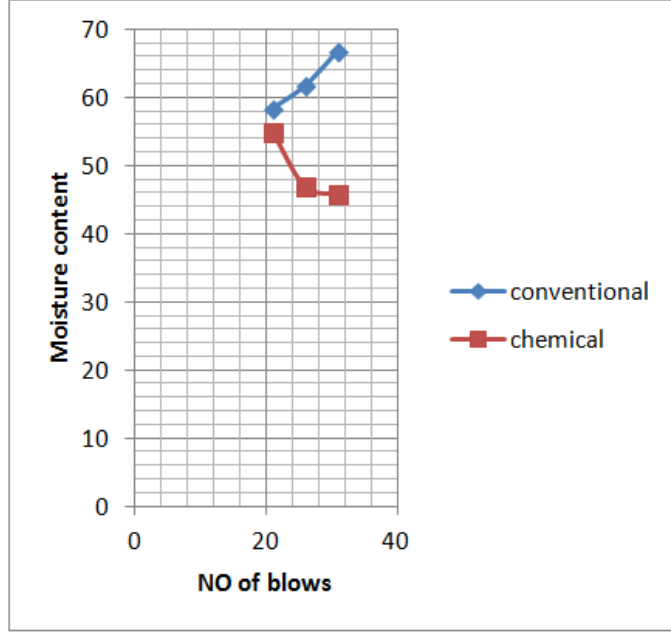

Fig. 16 Comparison of Flow Curves Between Conventional \& Chemically Treated B.C soil For LL.

\section{Plastic limit}

Table 30 Comparison Between Conventional \& Chemically Treated B.C soil For PL.

\begin{tabular}{|l|l|}
\hline Red soil & $\begin{array}{l}\text { Plastic } \\
\text { limit }\end{array}$ \\
\hline Conventional & $19.96 \%$ \\
\hline Chemical & $21.39 \%$ \\
\hline
\end{tabular}

Modified proctor test (Heavy Compaction)

Table 31 Comparision between Conventional \& Chemically Treated soil for Proctor Test.

\begin{tabular}{|l|l|l|}
\hline $\begin{array}{l}\text { Black cotton } \\
\text { soil }\end{array}$ & OMC & MDD \\
\hline Conventional & $10.25 \%$ & $\begin{array}{l}1.7 \\
\mathrm{gm} / \mathrm{cm}^{3}\end{array}$ \\
\hline Chemical & $14.5 \%$ & $\begin{array}{l}1.692 \\
\mathrm{gm} / \mathrm{cm}^{3}\end{array}$ \\
\hline
\end{tabular}

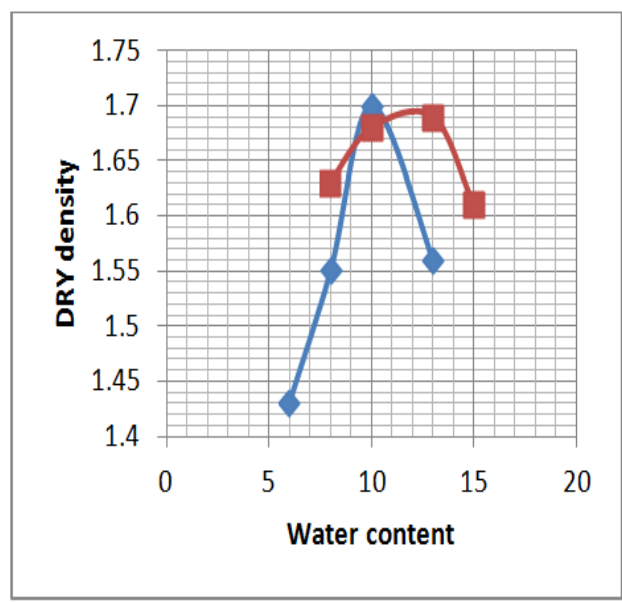

Fig. 17 Comparison of Compaction Curve between Conventional \& Chemically Treated B.C soil for Proctor Test.
C.B.R

Table 32 Comparison Between Conventional \& Chemically Treated B.C. soil For C.B.R.

\begin{tabular}{|l|c|}
\hline $\begin{array}{c}\text { 'Black cotton } \\
\text { soil }\end{array}$ & C.B.R \\
\cline { 1 - 1 } Conventional & \\
\hline @ 2.5mm & $8.69 \%$ \\
\hline @ 5mm & $7.78 \%$ \\
\hline Chemical & C.B.R \\
\hline$@ \mathbf{2 . 5 m m}$ & $10.84 \%$ \\
\hline @ 5mm & $20.17 \%$ \\
\hline
\end{tabular}

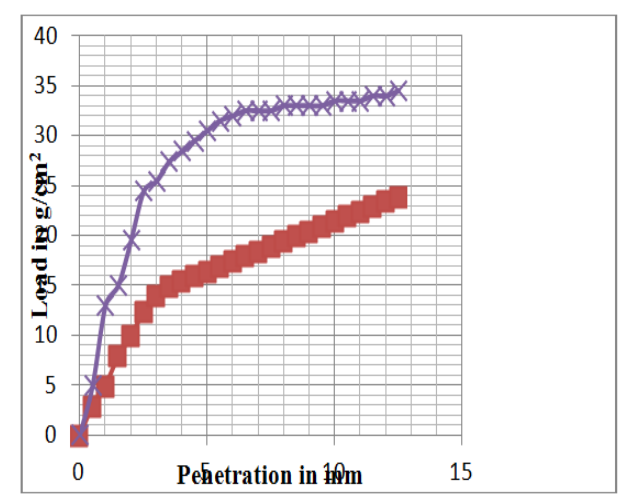

Fig. 18 Comparison of Load Penetration Curves between Conventional \& Chemically Treated B.C soil for C.B.R.

\section{CONCLUSIONS}

From laboratory results it was concluded that

1. Chemical stabilization had more CBR value than conventional method of soil stabilization.

2. Chemical stabilization required lesser thickness of subgrade in comparison with conventional stabilization.

3. By adding terresil plasticity index reduced and dry density increases.

4. Chemical stabilization was more economical than conventional stabilization.

\section{REFERENCES}

[1]. P. Venkaramuthyalu et al " study on performance of chemically stabilized expensive soil " IJAET jan 2012

[2]. R. saravan et al "A study on soil stabilization of clay soil using flyash ", International Journal of research in civil engineering architecture \& Design " vol. 1 Issue 2 oct -dec 2013 pp 333

[3]. Ankit negi et al "Soil stabilization using lime ,International Journal of Innovative in Science Engineering \& Technology vol. 2 Issue -2 feb. 2013

[4]. Waseim azzam et al "Durability of expansive soil using advanced nano composite stabilization, International journal of Gemate sept 2014 vol 7 no. 1 pp. 
927 geotech const. mat. \& Envirnonment ISSN 2186 -2982(P) 2186-2990 . Japan

[5]. Nandan A. Patel, Prof.C. B. Mishra, Mr. Vasu V. Pancholi, "Scientifically Surveying the usage of terrasil chemical for soil stabilization", International Journal of Research in Advent Technology, Vol.3, No.6, June 2015

[6]. Monika Malhotra et al " stabilization of expansive soil using low cost material", International Journal of engineering \& Innovative Technology (IJEIT) VOL. 2 Issue 11 may 2013

[7]. Olanlyan et al " soil stabilization techniques using sodium hydroxide additives " International Journal of Civil \& Environment engineering IJCEE vol . 2 No. 6

[8]. M. K. Gueddouda et al “ Chemical stabilization of expansive days from Algeria " Global journal of researches in engineering vol. II Issue 5 july 2011

[9]. Onyelowe ken c' et al “ A Comparitive review of soil modification Method " A PRN journal of Earth sciences vol. 1 no. 2 nov. 2012

[10]. Faisal ali " stabilization of Residual soil using Liquid chemical" EJGW volume 17 (2012) bund -B

[11]. Soil Mechanics and Foundations . ByDr.B.C Punmia, Ashok Kumar Jain \& Arun Kumar Jain. 